\title{
Evaluation of the dot enzyme-linked immunosorbent assay in comparison with standard ELISA for the immunodiagnosis of human toxocariasis
}

\author{
William Roldán ${ }^{+}$, William Cornejo, Yrma Espinoza
}

\author{
Instituto de Medicina Tropical “Daniel A. Carrión”, Facultad de Medicina, Universidad Nacional Mayor de San Marcos, \\ Calle José Santos Chocano 199, Callao, Perú
}

A dot enzyme-linked immunosorbent assay (dot-ELISA) was standardized using excretory-secretory antigens of Toxocara canis for the rapid immunodiagnosis of human toxocariasis. Thirty patients with clinical signs of toxocariasis, 20 cases with other parasitic diseases, and 40 healthy subjects were tested. A total of $0.2 \mathrm{ng}$ of antigen per dot, serum dilution of 1:160 and dilution conjugate of 1:1000 were found optimal. The sensitivity and specificity of the assay were 100 and 95\%, respectively. Comparable sensitivity of dot-ELISA and the standard ELISA was obtained, but only 3 cross-reactions occurred in the dot-ELISA, compared with 6 in the standard ELISA. Dot-ELISA is simple to perform, rapid, and low cost. Large-scale screening studies should be done to evaluate its usefulness under field conditions.

Key words: Toxocara canis - toxocariasis - dot enzyme-linked immunosorbent assay - ELISA

Human toxocariasis is a world-wide helminthic zoonosis due to the human infection by larvae of Toxocara canis, the common ascarid of dogs, and also by the cat ascarid T. cati (Schantz \& Glickman 1983, Despommier 2003). The incidence of human toxocariasis is unknown because toxocariasis is not a communicable disease in the majority of the countries. However, many cases of this disease have been reported throughout the world (Glickman \& Schantz 1981, Despommier 2003).

Humans are infected by ingestion of embryonated $T$. canis eggs. Children playing in areas contaminated with dog faeces are in higher risk, because of their likelihood of ingesting soil. Prevalence of Toxocara infestation of dogs and the resulting contamination of the ground is relatively high in many countries all over the world. Reported data range from 0 to $93 \%$ for dog infestation (Glickman \& Schantz 1981) and 15 to $78 \%$ for soil contamination (Gillespie 1988, Magnaval et al. 2001). It has been determined that in Peru from 24 to $80 \%$ of soil samples in public playgrounds and parks are contaminated with Toxocara eggs (Buitrón 1976, Guerrero 1995, Lescano et al. 1998, Chavez et al. 2000, Dávalos et al. 2000).

Although the clinical features vary, two syndromes are recognized: visceral larva migrans (VLM) and ocular larva migrans (OLM). VLM is usually detected in young children (1 to 5 years of age) with a history of geophagia and/or exposure to puppies. It is a self-limited, rarely lethal disease characterized by fever, cough, wheeze, pallor, malaise, asthma, weight loss, hepatomegaly, and marked eosinophilia (Schantz 1989). OLM occurs unilaterally in children and young adults and cause visual loss, strabis-

+Corresponding autor: willyroldan23@ hotmail.com Received 21 September 2005

Accepted 9 January 2006 mus and, more rarely, eye pain (Shields 1984). Another clinical manifestations of Toxocara infection are "common toxocariasis" in adults and "covert toxocariasis" in children (Schantz 1989, Magnaval et al. 2001).

Diagnosis of toxocariasis is based on clinical and serological data because of the difficulty in detecting larvae from tissues. The test currently employed for the serodiagnosis of toxocariasis is ELISA using excretory-secretory antigens from T. canis second-stage larvae (TES) (De Savigny et al. 1979, Jacquier et al. 1991). However, this technique has some drawbacks, including the need for trained personnel, requirement of special equipment, the lack of reproducible reading due to plate-to-plate variation, and may be troublesome to perform under field conditions. Dot-ELISA test, a modification of the standard ELISA test, offers a simple and less expensive tool for toxocariasis detection. The dot-ELISA has been successfully adapted for the detection of parasitic diseases in humans as leishmaniasis, schistosomiasis, toxoplasmosis, and hydatidosis (Pappas et al. 1984, Boctor et al. 1987, Rogan et al. 1991, Elsaid et al. 1995). Adot-ELISA for diagnosis of human toxocariasis was described (Camargo et al. 1992). The present study was conducted to standardize and evaluate a dot-ELISA to establish the optimal conditions for the detection of IgG antibodies to toxocariasis in comparison to the standard ELISA test.

\section{MATERIALS AND METHODS}

Obtention of fully embryonated Toxocara canis eggs - T. canis eggs were obtained by dissection of gravid adult female worms and left to embryonate for 30 days at $28^{\circ} \mathrm{C}$ in a mixture of $2 \%$ formalin and $1 \%$ sodium hypochlorite solution. Embryonated T. canis were washed repeatedly with sterile distilled water and decoated for $20 \mathrm{~min}$ in $5 \%$ sodium hypochlorite solution at $37^{\circ} \mathrm{C}$ (Espinoza et al. 2003). The egg suspension was then washed repeatedly in sterile distilled water until all traces of chlorine had been removed. 
Toxocara canis excretory-secretory antigens (TES) Fully embryonated $T$. canis eggs were hatched by mechanical treatment with sterile glass beads for 15 min and the larvae were collected in a Baermann apparatus (Lescano 1991). The TES antigen were produced according to De Savigny (1975) modified by Bowman et al. (1987). The supernatant from the Toxocara larvae cultures was removed each week, then dialyzed and concentrated using PEG 20,000 (mol. wt) (Sigma, US). The protein content of the TES antigen was estimated (Lowry et al. 1951) and finally kept in aliquots at $-20^{\circ} \mathrm{C}$ until use.

Ascaris suum adult stage extract - Adult worms were collected from swine intestine at local abattoir and washed in distilled water. Adult extract was prepared as described (Camargo et al. 1992) and protein concentration was estimated (Lowry et al. 1951) and finally kept in aliquots at $-20^{\circ} \mathrm{C}$ until use.

Absorption with A. suum extract - Each human serum to be assayed was absorbed (v/v) with soluble $A$. suum extract containing $52 \mu \mathrm{g} / \mathrm{ml}$ of antigen in order to remove nonspecific antibodies that might cross-react with TES antigen. After incubation at $37^{\circ} \mathrm{C}$ for $1 \mathrm{~h}$ dilutions of the absorbed sera were made and added to the nitrocellulose (NC) strips or microtitration wells.

Human sera - A total of 90 serum samples from 3 groups of persons were tested by standard ELISA and dot-ELISA. Group A included 30 sera from patients with clinical diagnosis of toxocariasis. Group B consisted of 20 sera from patients infected with helminths: Ascaris lumbricoides $(\mathrm{n}=3)$, Fasciola hepatica $(\mathrm{n}=3)$, Taenia $\mathrm{sp} .(\mathrm{n}=3)$, Strongyloides stercoralis $(\mathrm{n}=3)$, Hymenolepis nana $(\mathrm{n}=3)$, Trichuris trichiura $(\mathrm{n}=3)$, and larval stage of $T$. $\operatorname{solium}(\mathrm{n}=2)$. All infections were confirmed parasitologically except patients with cysticercosis, which were diagnosed by computed tomography findings and serological data. Group C comprised 40 serum samples from apparently normal children without evidence of toxocariasis.

Positive and negative reference samples were used to standardize the dot-ELISA. A positive reference serum was prepared by pooling 10 sera from patients with clinical diagnosis of toxocariasis with high (1024) and intermediate (512 to 256) titers in the ELISA test. A negative reference serum consisted of a pool of sera from clinically healthy and parasitologically negative children with no evidence of toxocariasis.

ELISA procedure - Standard ELISA was performed as reported by De Savigny et al. (1979) and Espinoza et al. (2003) with slight modifications. Briefly, 96-well microtiter polystyrene plates (Immulon $2 \mathrm{HB}$, US) were sensitized with a TES antigen solution $(100 \mu \mathrm{l} /$ well $)$ containing 12.5 $\mu \mathrm{g}$ of protein per $\mathrm{ml}$ in $0.05 \mathrm{M}$ bicarbonate buffer, $\mathrm{pH}$ 9.6, and then maintained for $18 \mathrm{~h}$ at $4^{\circ} \mathrm{C}$ in a moist chamber. The microtiter plates were washed 3 times with $0.15 \mathrm{M}$ phosphate-buffered saline-0.05\% Tween 20 (PBS/T) and then tested with a 1:128-diluted human serum sample (100 $\mu \mathrm{l} /$ well) in PBS/T containing 5\% nonfat skimmed milk powder for $60 \mathrm{~min}$ at $37^{\circ} \mathrm{C}$. The plates were washed 3 times with PBS/T and then $100 \mu \mathrm{l}$ of a 1:4000 dilution of antihuman IgG-peroxidase conjugate (Sigma, US) were added, to each well. After $60 \mathrm{~min}$ the plates were again rinsed and to each well was added $100 \mu \mathrm{l}$ of substrate solution, consisting of $o$-phenylenediamine (Sigma) 0.04 and $0.03 \%$ hydrogen peroxide diluted in $0.05 \mathrm{M}$ citrate-phosphate buffer, $\mathrm{pH} 5.0$, for approximately $30 \mathrm{~min}$, then stopped by the addition of $2 \mathrm{~N}$ sulphuric acid and the plates were read at $492 \mathrm{~nm}$, using an automatic microplate reader (Multiskan plus Labsystem version 2.01). The cut-off point was set at the mean optical density (OD) of the negative reference serum, plus 3 standard deviation (SD). Serum samples with OD $>0.26$ (cut-off) were considered as reactives.

Dot-ELISA procedure - The optimal conditions for dotELISA were standardized according to the procedures described by Boctor et al. (1987) with some modifications. Strips of NC paper (Sigma), $1 \mathrm{~cm}$ wide and $6 \mathrm{~cm}$ long were placed on a microtiter 96 -well plastic plate and after a slight pressure round areas were marked. Two microliters of several different TES antigen concentrations $(0.01-40 \mu \mathrm{g} / \mathrm{ml})$ were dotted on separate round areas. After drying, the free bindings sites on the paper were blocked by $18 \mathrm{~h}$ incubation at $4{ }^{\circ} \mathrm{C}$ in $0.01 \mathrm{M}$ phosphate-buffered saline (PBS), pH 7.2 containing 5\% defatted dry milk. Then, the strips were washed 3 times ( $5 \mathrm{~min} /$ wash) with PBS containing $0.05 \%$ Tween 20 . Twelve microliters of diluted serum (ranging from 1:40 to 1:320) were tested to determine the optimal working dilution. After $45 \mathrm{~min}$ at room temperature, they were washed as described above and incubated with 1:1000 dilution of goat anti-human IgG peroxidase conjugate (Sigma) for $45 \mathrm{~min}$ at room temperature. The strips were washed and soaked in freshly prepared substrate solution, which consisted of $0.5 \mathrm{mg}$ of 3,3'diaminobenzidine (Sigma) per milliliter and hydrogen peroxide $(0.01 \%)$ in $0.01 \mathrm{M}$ citrate buffer, $\mathrm{pH} 5.0$, for $5 \mathrm{~min}$. The reaction was stopped by washing with water and left to dry. The development of brown dots on NC was considered evidence of positively. The intensity of the color was judged by the naked eye, and numbers were on an arbitrary scale of $0 ;+;++;+++;$ or ++++ in reference to the negative control $(0)$.

Statistical analysis - For the determination of the dotELISA and micro-ELISA sensitivity, specificity and positive and negative predictive values, $2 \times 2$ tables were carried out.

\section{RESULTS}

Antigen concentration and serum and conjugate dilution - The optimal concentration of TES antigen, using standard positive and negative sera, revealed an optimum of $0.1 \mu \mathrm{g} / \mathrm{ml}$ (equivalent to $0.2 \mathrm{ng}$ per dot). The best cutoff for the detection of specific anti-Toxocara antibodies in sera was correspondent to $1 / 160$ dilution. However, minimum concentrations of TES $0.01 \mu \mathrm{g} / \mathrm{ml}$ (equivalent to 0.02 $\mathrm{ng} / \mathrm{dot}$ ) can be used to detect anti-Toxocara $\mathrm{IgG}$ at 1:320 serum dilutions. At all antigen concentrations, pooled normal sera gave negative results and nonspecific reactions were not found in either antigen or serum blank round areas. 1:1000 dilution of conjugate were found to be optimal for most preparations because they provide a clear discrimination of positive and negative reactions. 
Incubation time - The pooled positive and negative sera were incubated with antigen for a period of time varying from 30 to $60 \mathrm{~min}$, at room temperature. Best results could be observed after $45 \mathrm{~min}$. The optimum incubation time for the peroxidase conjugate was also $45 \mathrm{~min}$.

TES antigen fixation to nitrocellulose paper - In order to determine the most appropriate type of antigen dilution solution, the antigen was diluted in PBS or in buffered sodium carbonate bicarbonate solution $(0.02 \mathrm{M}$ $\mathrm{Na}_{2} \mathrm{CO}_{3} ; 0.03 \mathrm{M} \mathrm{NaHCO}_{3}, \mathrm{pH} 9.6$ ) with or without $2 \%$ ovoalbumin (OVA). Sodium bicarbonate buffer with $2 \%$ OVA was the better antigen dilution solution since the positive dot increases color intensity without affecting the negative dot color in the same strip.

Sensitivity and specificity of the dot-ELISA assay All 30 serum samples from patients with toxocariasis reacted positively, giving sensitivity of $100 \%$. The specificity was checked on 60 sera. From 20 sera of patients with different parasitic infections, one from a strongyloides case, one from fascioliasis case and one from teniasis case reacted positively, but not a single positive reaction was observed among the sera from 40 apparently normal individuals, giving a specificity of $95 \%$. When sera from all patients with different parasitic infections were repeatedly tested, the same cross-reaction was obtained.

Comparison of dot-ELISA with standard ELISA - All 30 sera investigated to detect IgG antibodies anti-Toxocara gave positive results by dot-ELISA and by standard ELISA. However, even after absorption with A. suum extract, standard ELISA showed positive results in 6 serum samples from the control group ( 3 from patients with teniasis, 1 with strongyloidiasis, 1 with fascioliasis, and 1 with cysticercosis) while only 3 serum samples from the same control group (1 patient with strongyloidiasis, 1 with fascioliasis and 1 with teniasis) were positive by dot-ELISA (Table I). Likewise, our results showed a good correlation between the visual grading of the dot-ELISA and the absorbance of ELISA (Table II).

\section{DISCUSSION}

The development of specific, sensitive, and reliable techniques to demonstrate the presence of antibody in toxocariasis is an important step towards improving diagnosis. In this study, we evaluated a simple and sensitive dot-ELISA test for the immunodiagnosis of human toxocariasis. Conventional ELISA procedures require larger volumes of soluble antigen (De Savigny et al. 1979,
TABLE II

Comparison between standard ELISA absorbance and dotELISA positivity

\begin{tabular}{lcc}
\hline $\begin{array}{l}\text { dot-ELISA } \\
\text { scale }\end{array}$ & ELISA & $\begin{array}{c}\text { Nr of } \\
\text { samples tested }\end{array}$ \\
\hline+4 & $\mathrm{~A}_{492 \mathrm{~nm}}$ & 2 \\
+3 & $1.47-1.55$ & 10 \\
+2 & $1.11-1.38$ & 8 \\
+1 & $1.01-1.09$ & 16 \\
0 & $0.29-0.98$ & 54 \\
\hline
\end{tabular}

Espinoza et al. 2003), whereas the dot-ELISA uses only minute amounts of TES antigen per test ( $0.2 \mathrm{ng}$ total protein per dot in contrast to $1.25 \mu \mathrm{g}$ per microtitration well). We found that the best result to fix TES antigen to NC sheets was obtained with sodium bicarbonate buffer with $2 \%$ OVA which could be responsible for the need for lesser antigen concentration than previously reported (Camargo et al. 1992). Simplification of the procedure can be achieved by the use of large NC strips (Boctor et al. 1987), mass production of NC strips (Janitschke et al. 1987), and the use of the commercially available Bio-dot apparatus (Chan $\&$ Ko 1988). Another advantage of this method is that it is simple, rapid (about $2 \mathrm{~h}$ ), does not need expensive equipment, results can be read visually, a large number of samples can be assayed, and the test is performed at room temperature.

The sensitivity of dot-ELISA and standard ELISA was similar (100\%) as previously reported (Camargo et al. 1992), whereas specificity of the dot-ELISA was higher than standard ELISA. The healthy control sera were negative by both tests and other parasites-positive group, 3 out of 20 sera gave a positive reaction in the dot-ELISA and 6 out of the same subjects were positive for ELISA. The positive reactions observed specially with ELISA was undetermined but may include the presence of common antigens between Toxocara antigens and several other infectious agents commonly occurring in underdeveloped countries and previous unapparent past infections with Toxocara species. Previous absorption of sera with $A$. suum antigen extract, does not eliminate all cross-reactions, as reported (Camargo et al. 1992).

ELISA is the most commonly utilized diagnostic serologic test for VLM, OLM, and covert toxocariasis, the most frequent clinical syndromes associated with Toxocara

TABLE I

Sensitivity, specificity, positive, and negative predictive values for dot-ELISA and standard ELISA tests

\begin{tabular}{lcr}
\hline & Performance index & Serology test \\
\cline { 2 - 3 } & Dot-ELISA $(\%)$ & Standard ELISA (\%) \\
\hline Sensitivity & $100^{a}$ & 100 \\
Specificity & $95(84-100)$ & $90(82-98)$ \\
Positive predictive value & $90.9(81-100)$ & $83.3(71-96)$ \\
Negative predictive value & 100 & 100 \\
\hline
\end{tabular}

$a$ : confidence interval (95\%) 
infections. However, the serum ELISA for Toxocara-specific IgG is less sensitive for the diagnosis of OLM than for other forms of the disease (Magnaval et al. 2001, Despommier 2003). Therefore, confirmation of ocular toxocariasis can be obtained by testing aqueous or vitreous fluid. Dot-ELISA here presented has not yet been performed with sera or intraocular fluids of patients with OLM but we think this test will not only improve the diagnosis of VLM because its specificity is higher than the indirect ELISA but also the diagnosis of ocular toxocariasis.

The dot-ELISA for toxocariasis, as reported here, is a specific means of establishing serological diagnosis of the disease. The dot-ELISA can be used as a qualitative test to screen large number of samples and can be further developed as a field detection method.

\section{ACKNOWLEDGEMENTS}

To Dr Hilda Solís, Instituto de Medicina Tropical "Daniel A. Carrión", for kindly supplying the nitrocellulose sheets.

\section{REFERENCES}

Boctor FN, Steck MJ, Peter JB, Kamal R 1987. Simplification and standardization of dot-ELISA for human schistosomiasis mansoni. J Parasitol 73: 589-592.

Bowman DD, Mika-Grieve M, Grieve RB 1987. Circulating excretory antigens levels and specific antibody responses in mice infected with Toxocara canis. Am J Trop Med Hyg 36: $75-82$.

Buitrón LA 1976. Estudio de la Contaminación de Áreas de Uso Público con Huevos de Toxocara sp. en el Área Urbana de Paramonga, Distrito de Pativilca-Provincia de Chancay, Departamento de Lima, Bachiller Thesis, Facultad de Medicina Veterinaria, Universidad Nacional Mayor de San Marcos, Perú, 25 pp.

Camargo ED, Nakamura PM, Vaz AJ 1992. Standardization of dot-ELISA for the serological diagnosis of toxocariasis and comparison of the assay with ELISA. Rev Inst Med Trop São Paulo 34: 55-60.

Chan SW, Ko RC 1988. Comparison between standard ELISA and dot-ELISA for serodiagnosis of human trichinosis. Trans $R$ Soc Trop Med Hyg 82: 892-894.

Chavez A, Casas E, Cajas J, Velarde J 2000. Contaminación de parques públicos con huevos de Toxocara sp. en los distritos de la provincia constitucional del Callao y del cono sur de Lima Metropolitana. Rev Invest Vet Per 11: 52-57.

Dávalos M, Pachas O, Perez V 2000. Toxocariosis en Canis familiaris y suelo en el Distrito de Chincha Alta (19981999). In IV Congreso Peruano de Parasitología, 22-24 de Setiembre, Lima-Perú, Abstract, p. 215.

De Savigny DH 1975. In vitro maintenance of Toxocara canis larvae and a simple method for the production of Toxocara $\mathrm{E} / \mathrm{S}$ antigen for use in serodiagnostic tests for visceral larva migrans. J Parasitol 61: 781-782.

De Savigny DH, Voller A, Woodruff AW 1979. Toxocariasis: serological diagnosis by enzyme immunoassay. J Clin Pathol 70: 284-288.

Despommier D 2003. Toxocariasis: clinical aspects, epidemiol- ogy, medical ecology, and molecular aspects. Clin Microbiol Rev 16: 265-272.

Elsaid MMA, Bahia MT, Machado-Coelho GL, Vitor RW 1995. Diagnosis of human toxoplasmosis by a dot enzyme-linked immunosorbent assay. Rev Inst Med Trop São Paulo 37: 117-122.

Espinoza Y, Huapaya P, Suarez R 2003. Estandarización de la técnica de ELISA para el diagnóstico de la toxocariosis humana. Anal Fac Med 64: 7-12.

Gillespie SH 1988. The epidemiology of Toxocara canis. Parasitol Today 4: 180-182.

Glickman LT, Schantz PM 1981. Epidemiology and pathogenesis of zoonotic toxocariasis. Epidemiol Rev 3: 230-250.

Guerrero MD 1995. Estudio de la Contaminación de Parques Públicos de Lima Metropolitana con Huevos de Toxocara sp. Lima, Thesis, Facultad de Medicina Veterinaria, Universidad Nacional Mayor de San Marcos, Perú, 12 pp.

Jacquier P, Gottstein B, Stinlegin Y, Eckert J 1991. Immunodiagnosis of toxocariasis in humans: evaluation of a new enzyme-linked immunosorbent assay kit. J Clin Microbiol 29: 1811-1835.

Janitschke K, Reinhold A, Bode L 1987. Nitrocellulose dotELISA for serodiagnosis of schistosomiasis. Trans $R$ Soc Trop Med Hyg 81: 956-958.

Lescano SAZ 1991. Estudio Epidemiológico da Toxocariase na Área Urbana de Lima, Perú, MSc Thesis, Instituto de Ciencias Biomédicas da Universidade de São Paulo, São Paulo, $50 \mathrm{pp}$.

Lescano SAZ, Chieffi PP, Peres BA, De Mello EO 1998. Soil contamination and human infection by Toxocara sp. in the urban area of the Lima, Perú. Mem Inst Oswaldo Cruz 93: 733-734.

Lowry OH, Rosenbrough NJ, Farr AL, Randall RJ 1951. Protein measurement with the folin phenol reagent. $\mathrm{J}$ Biol Chem 193: 265-275.

Magnaval JF, Glickman LT, Dorchies P, Morassin B 2001. Highlights of human toxocariasis. Korean J Parasitol 39: 1-11.

Pappas MG, Hajkowski R, Hockmeyer WT 1984. Standardization of the dot enzyme-linked immunosorbent assay (DOT-ELISA) for human visceral leishmaniasis. Am J Trop Med Hyg 33: 1105-1111.

Rodríguez V, Muñiz F 2000. Toxocara canis en excretas de perros, suelos y vegetales de calles, plazas y áreas recreacionales de Cuzco urbano. In IV Congreso Peruano de Parasitología, 22-24 de Setiembre, Lima-Perú, Abstract, p. 224.

Rogan MT, Craig PS, Zeyhie E 1991. Evaluation of a rapid dotELISA as a field test for the diagnosis of cystic hydatid disease. Trans R Soc Trop Med Hyg 85: 773-777.

Schantz PM 1989. Toxocara larva migrans now. Am J Trop Med Hyg 41: 21-34.

Schantz PM, Glickman LT 1983. Ascáridos de perros y gatos: un problema de salud pública y medicina veterinaria. Bol Oficina Sanit Panam 94: 571-586.

Shields JA 1984. Ocular toxocariasis. A review. Surv Ophthalmol 28: 361-381. 